\title{
GEOGRAPHY OF OPPORTUNITY AND RESIDENTIAL MORTGAGE FORECLOSURE: A SPATIAL ANALYSIS OF A U.S. HOUSING MARKET
}

\author{
Yanmei LI \\ Florida Atlantic University, U.S.A.
}

\begin{abstract}
South Florida has been among the top foreclosure markets in the United States, but little research has explored whether this market presents different dynamics compared to other metropolitan areas. This research chooses Broward County to explore whether socioeconomic characteristics and certain public policy instruments relate to subprime lending and mortgage foreclosure patterns. Results indicate areas bounded by linear highways and railroads have a concentration of low-income black population and subprime loans. The spatial distribution of subprime loans is mostly explained by a higher percentage of minority and/or Hispanic population in a neighborhood. Yet, racial minorities, instead of Hispanic origin, contributes mostly to the concentration of subprime loans. The spatial pattern of foreclosures is more complex, determined not only by subprime loans but also possibly other factors associated with the mortgage crisis. This suggests that disadvantaged neighborhoods are disproportionally lacking favorable opportunities due to institutional and sub-cultural forces shaping the geography of subprime and foreclosure.
\end{abstract}

Key Words: mortgage foreclosure, subprime, neighborhood, geography of opportunity

\section{Introduction}

Sharply rising mortgage foreclosure rates during the economic recession between 2007 and 2009 have drawn a significant amount of attention from scholars and policy makers. There has been an abundance of research probing factors, particularly subprime lending and neighborhood characteristics, contributing to foreclosures (e.g. Stock 2001, National Association of Realtors 2004, Goldstein 2004, Rhey and Posner 2004, Grover et al. 2008). Subprime loans are originated to cater the needs of risky borrowers with impaired credit history or scores. These loans typically have high interest rates ${ }^{1)}$ and are sold in separate markets from prime mortgages. Most research finds that neighborhoods with concentrated low income minority population have been associated with a large amount of subprime loans, foreclosure filings, and foreclosed properties. Florida has been among the top foreclosure markets in recent years but little research has been conducted to explore the inter-linkage between neighborhoods, subprime and foreclosures.

Subprime lending has been blamed as one of the leading causes of the housing and foreclosure crisis during the economic recession (Coleman et al. 2008). Although housing bubbles and market speculation played some roles in stimulating foreclosures, abundant research has indicated that foreclosures are concentrated in certain neighborhoods where the

1) High-cost loans (subprime loans) were those with annual percentage rates (APR) about $3 \%$ higher than the rate on Treasury securities with comparable maturity for the first-lien mortgages, and about $5 \%$ above the Treasury rate for the second-lien mortgages. 
share of high-cost subprime mortgages is high (Apgar and Duda 2004, Immergluck and Smith 2005, Goldstein et al. 2005, National Association of Realtors 2004). At the same time due to housing market segregation and "green lining" (indicated as easy credit access for disadvantaged people or in disadvantaged communities) (e.g. Wyly 2002, Newman and Wyly 2004) subprime lending heavily concentrates in low income minority neighborhoods, particularly low income black neighborhoods (Bocian et al. 2008, Nichols et al. 2005, Courchane et al. 2004, Goldstein 2004, The U.S. Department of Housing and Urban Development and the U.S. Department of Treasury 2000, Belsky and Drew 2005). These neighborhoods used to be victims of "red lining" (illegal practice of denying credit services to communities of color) and later "brown lining"- the so called LULU (locally undesirable/ unwanted land uses) - and "green lining" (Wyly 2002, Newman and Wyly 2004, Fitzgerald and Leigh 2002). Thus these low income minority neighborhoods have been the target of many unfair policies and practices in credit and capital access. In addition to suffering from inadequate (or too much and too easy) credit access, these areas are often negatively influenced by land use, environmental planning, and transportation planning decisions (Schively 2007, Been 1994). Therefore, geography of opportunities and the segmentation of housing market play critical roles influencing socioeconomic wellbeing of these neighborhoods and their residents. Different from most of the previous research, this study attempts to integrate locational opportunity variables, such as land use and transportation planning, to assess how they relate to the spatial distribution of wealth, subprime and foreclosures.

Like other metropolitan areas in the United States, the tri-county South Florida region (Palm Beach County, Broward County, and Miami-Dade County) also has distinctive divisions of wealth, subprime, and foreclosure patterns (see the distribution in Broward County in Figures 2 -5). This region has followed similar patterns of urban uneven development, manifested by sprawl, concentrated poverty, and housing market segmentation (Squires and Kubrin 2005). South Florida has more than $20 \%$ Hispanic population, yet the geography of opportunities mostly reflects the segregation between whites and blacks. Due to constraints in land use, the growth in South Florida distinctively follows a north-south linear stretch for over 180 miles. Most of the major highways and public transit lines therefore follow a linear pattern, with intermittent local expressways or roads running east-west. Three major highways, I-95, Florida's Turnpike, and U.S. Highway 1 (U.S. 1), help shape three major zones of the land use structure. East of U.S. Highway 1 is full of affluent beach or waterfront houses and highrise condominiums. The area between U.S. 1 and Florida's Turnpike is mostly featured by industrial uses and low-income minority neighborhoods. West of Florida's Turnpike is mostly wealthier communities, more so in areas adjacent to the Everglades National Park. The distinctive urban landscape in South Florida and the troubling foreclosure crisis imposes significant obstacles and challenges in redevelopment and reuse of vacant properties to accommodate future growth.

This paper explores the spatial patterns of demographic characteristics, land use, subprime and foreclosure, and how geography of opportunity, subprime, and foreclosures relate to each other. The paper starts with a brief background introduction of determinants of subprime lending, and how subprime relates to foreclosures. This is followed by data and methodology, and a description of the socioeconomic characteristics of South Florida. Spatial distribution of various subprime and foreclosure factors is analyzed and the results of regression models are then discussed.

\section{Background and Literature Review}

Many factors determine the mortgage default risk of specific loans, but loan-to-value ratio 
(LTV), payment-to-income ratio, householder's occupation (i.e., whether the householder has a volatile or stable income), property and neighborhood condition, regional unemployment rate, transaction costs, crisis events, and borrowers' expectations are some of the major elements considered in the literature (Quercia and Stegman 1992, HUD 1992, Vandell and Tribodeau 1985). Many of these factors are also related to the type of loans that the borrowers carry.

Previous research has found that subprime loans have contributed significantly to the rising foreclosure trend since late 1990s. The role of subprime and predatory lending on increasing mortgage foreclosures is addressed by many previous studies and in different states such as Ohio, Indiana and Arizona (Goldstein 2004, Rhey and Posner 2004, Stock 2001). Neighborhood effects on subprime lending and foreclosures have not drawn sufficient attention until recently. After controlling for borrower and loan characteristics, many scholars found that neighborhoods with a concentration of low income racial minorities tend to have higher foreclosure rates (Chan et al. 2010, Immergluck and Smith 2005, Goldstein et al., 2005, Apgar and Duda 2004, National Association of Realtors 2004, Bocian et al. 2008, Nichols et al. 2005, Courchane et al. 2004, Goldstein 2004, The U.S. Department of Housing and Urban Development and the U.S. Department of Treasury 2000, Belsky and Drew 2005). All the research on neighborhoods, subprime loans, and foreclosures indicates that place matters in the spatial patterns of subprime loans and foreclosures (Chan et al. 2010).

\section{Geography of Opportunity and Credit Access}

Place and race have helped shape the American urban landscape and residential mobility patterns (Squires and Kubrin 2005, Rosenbaum et al. 2002). The inter-relationship of place, race, and privilege is largely determined by spatial patterns of urban sprawl, concentrated poverty and housing market segregation. Physical features such as rivers, railroads, and highways in an urban setting can function as the natural barriers of residential neighborhood sorting (Noonan 2006), especially if planned in a manner to unintentionally increase separation and segregation.

As location matters in real estate, place and "geography of opportunity" influences opportunities that individuals encounter. Thus "geography of opportunity" modifies "the innate and acquired characteristics of participants ... [and their] ability to plan and sacrifice for the future" (Galster and Killen 1995, p. 9, 12). Galster and Killen (1995) further contend that individuals' options are limited by the real and perceived socioeconomic conditions of our environment, whether the perception is accurate or rational. Therefore, settlement patterns under the influence of culture, social networks, and public policies constrain individual opportunities in capital access, education, public services, or employment. Community Reinvestment Act (CRA) ensures fair credit access to all neighborhoods, yet many conventional lenders, such as commercial banks, credit unions, and savings institutions, tend to concentrate in wealthier neighborhoods. The "fringe bankers", such as chequecashers, payday loans, and pawn shops, are often in central-city lower income neighborhoods (Squires and Kubrin 2005, Caskey 1994, 2002, Sawyer and Temkin 2004).

Therefore the geography of opportunities has helped shape the spatial patterns of credit access. Sandor and Sosin (1975) found that neighborhood conditions were negatively related to the mortgage interest rates. But they did not further explain whether those conditions were related to mortgage discrimination or perceived higher risk in lower quality neighborhoods; or whether they were caused by the aggregation of individual borrowers with weak credit. 
Historically, "red lining" prohibited credit access of residents in neighborhoods with concentrated racial minorities. The invention of exotic mortgage products (Immergluck 2008 ) in the 1990s to help promote homeownership rates have granted easy access of capital in formerly "red lined" areas. As an innovative financial product to extend credit to borrowers who have difficulty getting a mortgage in a prime market, subprime mortgages have played important roles in enhancing homeownership rates since the mid 1990s (Bostic and Lee 2007). However, the share of subprime mortgages in outstanding mortgage loans increased from $2.4 \%$ in 1998 to $13.4 \%$ in 2006 (Duncan 2006), which inevitably contributes to the severe mortgage foreclosure issues between 2006 and 2010.

Credit risks, along with racial backgrounds and other demographic characteristics such as age (Immergluck and Smith 2005) of the borrowers, is often associated with the likelihood of seeking (or being targeted by) high-cost subprime lending (Grover et al. 2008), including highcost refinance and investor mortgages. About $25 \%$ of subprime refinance loans concentrate in lower income and minority neighborhoods, compared to approximately $9 \%$ in wealthier and white neighborhoods (Belstky and Drew 2005). Some of the scholars, such as Newman and Wyly (2004) argue that it is possible that subprime lenders deliberately target minority neighborhoods with older housing stock and a history of mortgage redlining and discrimination. The distrust of mainstream financial institutions from the homebuyers within these neighborhoods exacerbated the problem.

Housing segregation associated with historical redlining determines the clusters of homeowners based on socio-economic characteristics (Newman and Wyly 2004). Thus vulnerable borrowers and subprime loans tend to cluster in vulnerable neighborhoods (Rugh and Massey 2010). In addition to race and income, Calem et al. (2004) found that the share of subprime loans in a neighborhood is negatively related to neighborhood education level. Additionally, Kingsley and Pettit (2009) argue that contrary to most beliefs, the highest concentration of subprime mortgages is in minority neighborhoods with the lowest poverty rates. This might indicate that foreclosures mostly concentrate in neighborhoods with younger homeowners (or renters) who were able to afford their first home, yet later lost the home to foreclosure. Thus different socioeconomic and public policy factors contribute to the concentration of subprime lending.

\section{Subprime Lending and Mortgage Foreclosure}

Due to its high cost nature, subprime lending contributes greatly to the rising housing costs burden on lower-income households (Gramlich 2007). This has made subprime mortgages one of the leading determinants of the levels of mortgage foreclosures in a neighborhood (Immergluck and Smith 2005, Goldstein et al. 2005, Apgar and Duda 2004, National Association of Realtors 2004). Payment shocks from subprime and innovative mortgages (such as adjustable rate mortgages (ARMs), interest only loans, balloon payments, buydown loans and other products, buyers' lack of knowledge about subprime loans, along with other factors (such as housing affordability, home maintenance costs, property taxes, property insurance, home furnishing costs and home repair costs, economic downturn, negative equity and the burst of the housing bubble), have made it difficult for vulnerable borrowers to keep up with their mortgages. Subprime borrowers are particularly the case. Among abundant literature about neighborhood patterns of subprime lending, none has incorporated land use and transportation factors in probing the geography of opportunities, and how it relates to the concentration of subprime lending and foreclosures. Socioeconomic variables examined in previous research often are not comprehensive. This research incorporates demographic, 
economic, housing, and land use factors to measure the relationship between neighborhoods, subprime, and foreclosures. Furthermore, this paper will be the first attempt to examine how South Florida is different in terms of the relationship between neighborhoods, subprime, and foreclosures.

Land use planning and public policies explain the external factors regulating the evolution of neighborhoods and construe the political economy of neighborhood change (Temkin and Rohe 1996). Neighborhood characteristics, aggregated from characteristics of individual residents, manifest the dimension of ecological and sub-cultural theory of neighborhood change (Burgess 1925, Hoyt 1933, Smith 1963, Sweeney 1974, Birch 1971, Rothenberg et al. 1991). The outcomes of external and internal factors determining neighborhood characteristics and changes helped shape the geography of opportunities and the distribution of subprime lending and foreclosures. The concentration of subprime loans and foreclosures further degrade neighborhoods, yet, the degradation might create opportunities of revitalization and reinvestment when favorable conditions arise (Li and Morrow-Jones 2010).

\section{The South Florida Contexts and the Research Hypotheses}

The three counties in South Florida, Miami-Dade, Broward and Palm Beach, have close relationship in housing, transportation, and employment. Located between Miami-Dade and Palm Beach, Broward County has a diverse population and sends out the largest number of commuters to the other two counties (SEFTC 2009). Among the three counties, Miami-Dade has the largest foreign-born and Hispanic population while most of the population in Palm Beach County is non-Hispanic white. The wealth and racial composition in Broward County is in between Miami-Dade and Palm Beach Counties ${ }^{2}$. However, population shifts indicate that the percentage Hispanic population in Broward and Palm Beach counties is rising over the years.

South Florida has been among the top foreclosure markets since 2006, when the housing boom reached its peak and the housing market started cooling ${ }^{3)}$. In December 2008 there were nearly 369,000 foreclosure case filings in Florida. In December 2009 it was estimated that there were an inventory of approximated 456,000 pending foreclosure cases statewide. Up to the end of 2009 Florida has the third highest mortgage delinquency rate, the worst foreclosure inventory, and the largest number of foreclosure starts in the nation (Supreme Court of Florida 2009). In 2011 foreclosure filings dropped significantly (about 69\% compared to February $2010^{4}$ ). However, the issue of foreclosure remains outstanding. From January to March 2011 there were 40,431 properties in Florida filed for foreclosures. In February alone, the new filings were 18,760 (RealtyTrac.com 2011).

Broward County was established in 1915 and named after former Florida Governor Napoleon

2) For example, based on the American Community Survey (2005-2009) median household income in Miami-Dade was $\$ 42,969$ (in 2009 inflation-adjusted dollars), in Broward was $\$ 51,731$, and in Palm Beach was $\$ 53,538$. Percentage black population was $19.6 \%, 24.4 \%$, and $15.8 \%$ respectively. Percentage Hispanic population was $61.4 \%, 23.1 \%$, and $17.1 \%$ respectively.

3) The ranking of the top foreclosure markets is mostly based on CNN and RealtyTrac rankings Detailed foreclosure information can be also obtained from Foreclosure Response (http://foreclosureresponse.org/), a nonprofit organization focusing on educating and information sharing about foreclosure and its impact.

4) Based on a report from CondoVultures.com, retrieved from the following website: http://condovultures.com/News/ViewArticle/tabid/77/Articleld/20473/South-Florida-Foreclosure-Filings-Drop$\underline{69-I n-F e b r u a r y-2011 . a s p x . ~}$ 
Bonaparte Broward. Based on the U.S. Census data its estimated total population in 2009 was 1.7 million. It has 28 incorporated towns and cities in Broward, with Ft. Lauderdale being the largest city and the county seat. The County's economy is largely based on retailing, light industry and service. The economic and housing boom has dramatically helped appreciate housing prices in the county. During the economic recession, loss of jobs and the slump of housing prices have thrown thousands of households into mortgage foreclosure, particularly those with subprime loans. Broward County has been among the top foreclosure markets in Florida and the U.S. Areas bounded by linear highways have a large portion of blacks, subprime loans, and non-strategic foreclosures. ${ }^{5}$ )

In summary, previous research has explored how race and other demographic characteristics relate to subprime and foreclosures. This research extends previous hypotheses by including the following three dimensions of hypotheses: 1) Institutional forces helped shape the distribution of wealth, race, and ethnicity; 2) Further, subprime lending and foreclosure concentrate in neighborhoods with a high percentage of low income black population; 3) Given the South Florida context, Hispanic and foreign-born population also significantly contribute to the spatial concentration of subprime and foreclosures.

Thus there are two major contributions of this research. First, it considers the sequential linkage between political and institutional influences, demographic and housing characteristics, subprime, and foreclosures (see Fig. 1). Foreclosures in turn can affect all these factors. This paper does not focus on the recursive linkage between these factors and foreclosures.

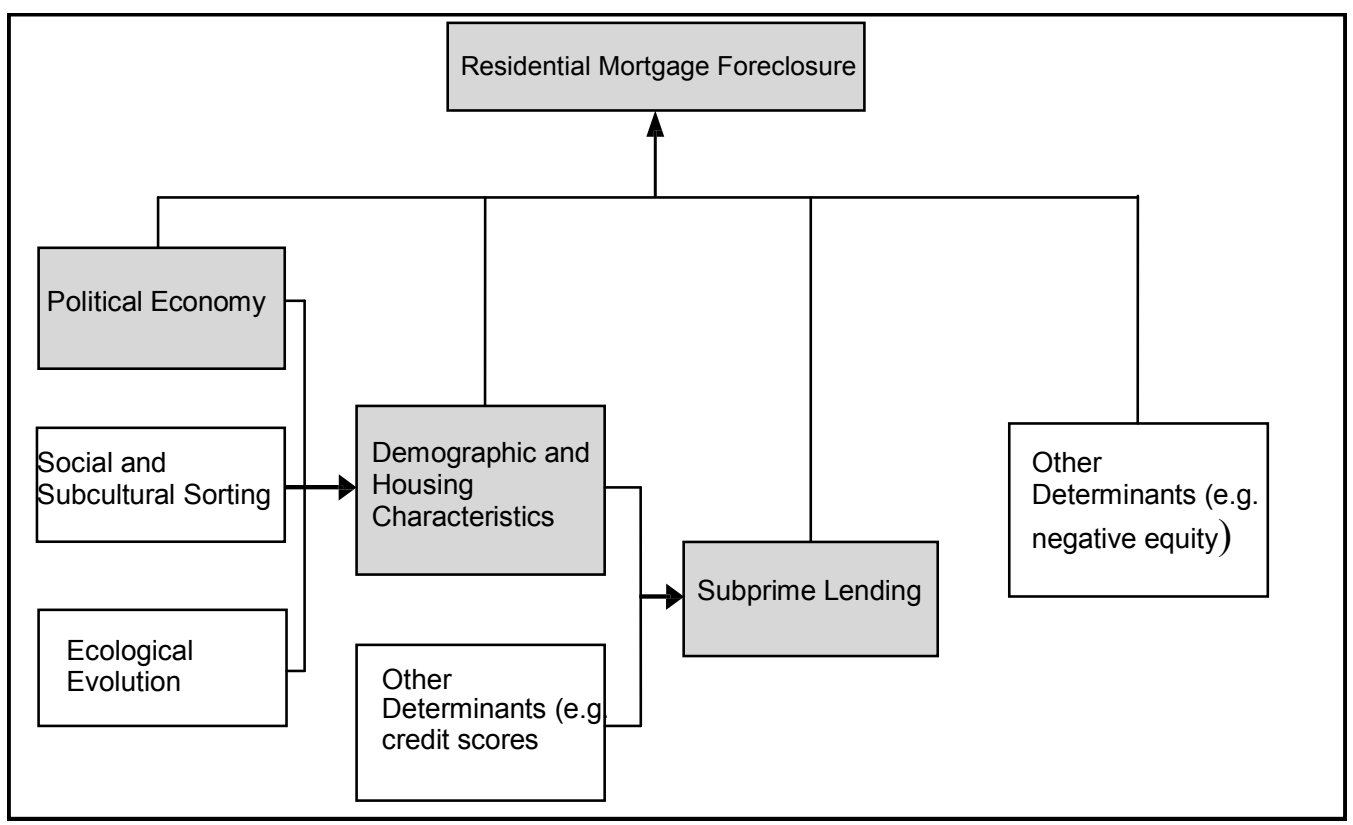

Fig. 1 - Theoretical Framework

5) Strategic foreclosures indicate those voluntary foreclosures of homes because of the sharply dropping housing prices for underwater properties. It was reported by Miami Herald and other agencies that more than half of Florida's homes (about 2.1 million) were underwater in March, 2011. 
Secondly, this paper is also the first academic study to explore how these factors interact in South Florida, particularly given the unique physical and socioeconomic characteristics of the region.

\section{Data and Methods}

Variables. In answering the research questions the variables are divided into four different categories: foreclosure and subprime rates, demographic characteristics, housing structural characteristics and land use characteristics. Detailed variable description and descriptive statistics for each variable by census block groups are illustrated in Table 1.

Table 1

List of variables and descriptive statistics

\begin{tabular}{|c|c|c|c|c|c|}
\hline Variable & Description & Mean & Std Dev & Minimum & Maximum \\
\hline \multicolumn{6}{|c|}{ Foreclosure and Subprime Rates (Dependent Variables) } \\
\hline FORERATE & Residential foreclosure rate (2007-early 2009) & 2.68 & 1.79 & 0.00 & 11.6 \\
\hline SUBPRIME & Percentage subprime loans (2004-2006) (\%) & 30.06 & 13.22 & 6.33 & 60.9 \\
\hline \multicolumn{6}{|c|}{ De mographic Characteristics (In de pen de nt Variables) } \\
\hline POP2008 & Estimated total population in 2008 & 2,588 & 2,272 & 0 & 21,57 \\
\hline HH2008 & Estimated total number of hous eholds in 2008 & 1,014 & 845 & 0 & 6,23 \\
\hline UNEMPLOY & Estimated unem ploym ent rate in $2008(\%)$ & 5.94 & 4.97 & 0.00 & 41.9 \\
\hline INCOME & Estimated median hous ehold income in 2008 & $54,122.24$ & $24,397.97$ & 0.00 & $158,653.8$ \\
\hline PCTHISP & Estimated percentage his panic population in 2008 (\%) & 20.87 & 13.97 & 0.00 & 77.4 \\
\hline PCTWHITE & Estimated percentage white population in $2008(\%)$ & 62.88 & 29.44 & 0.00 & 99.2 \\
\hline РСТВLACK & Estimated percentage black population in $2008(\%)$ & 26.07 & 28.67 & 0.00 & 98.7 \\
\hline MINORITY & Estimated percentage minority population in $2008(\%)$ & 36.83 & 29.31 & 0.00 & 100.0 \\
\hline AVGAGE & Estimated average population age in 2008 & 39.69 & 9.09 & 0.00 & 80.6 \\
\hline COLLEDU & Estimated percentage population with college education in $2008(\%)$ & 35.38 & 14.50 & 0.00 & 76.3 \\
\hline FOREIGN & Percentage foreign-born population in $2008(\%)$ & 34.33 & 22.69 & 0.00 & 100.0 \\
\hline NEWIMM & Percentage new immigrants (\%, entered the U.S. between $1990-2000$ ) & 9.73 & 8.03 & 0.00 & 100.0 \\
\hline CGWHITE & Change in percentage white population (2000-2008) & -6.47 & 6.33 & -29.85 & 15.9 \\
\hline CGBLK & Change in percentage black population $(2000-2008)$ & 4.12 & 5.93 & -17.39 & 60.2 \\
\hline CGHISP & Change in percentage His panic population $(2000-2008)$ & 5.66 & 7.07 & -100.00 & 33.6 \\
\hline CGFORE & Change in percentage foreign-born population $(2000-2008)$ & 10.49 & 12.62 & -100.00 & 90.7 \\
\hline CGEDU & Change in percentage population with college education $(2000-2008)$ & 5.87 & 7.57 & -21.91 & 26.3 \\
\hline CGUNEMP & Change in unem ployment rate $(2000-2008)$ & 0.06 & 1.63 & -3.30 & 41.9 \\
\hline C GINC & Percentage change in median hous ehold income $(2000-2008)$ & 0.22 & 0.09 & -4.57 & 100.0 \\
\hline \multicolumn{6}{|c|}{ Housing Attributes (In dependent Variable s) } \\
\hline РСТОсC & Estimated housing vacancy rate in $2008(\%)$ & 10.03 & 10.83 & 0.00 & 100.0 \\
\hline TENURE & Es timated homeowners hip rate in 2008 (\%) & 68.00 & 24.45 & 0.00 & 99.2 \\
\hline VALUE & Estimated median housing value in 2008 & 307.244 .83 & $174,159.91$ & 0.00 & $1,099,999.0$ \\
\hline РСТНMP & Percentage subprime home purchase loans (2004-2006) (\%) & 14.10 & 5.49 & 2.65 & 32.6 \\
\hline PCTOWN & Percentage subprime owner-purchase loans (2004-2006) (\%) & 11.33 & 4.59 & 1.90 & 24.4 \\
\hline PCTINV & Percentage subprime investor purchase bans $(2004-2006)(\%)$ & 2.78 & 2.04 & 0.00 & 13.8 \\
\hline PCTREF & Percentage subprime refinance loans $(2004-2006)(\%)$ & 15.96 & 9.09 & 1.27 & 42.9 \\
\hline PCTSING & Percentage single-family housing units in $2009(\%)$ & 79.46 & 25.40 & 0.00 & 100.0 \\
\hline PCTMUL & Percentage multi-family housing units in $2009(\%)$ & 9.93 & 16.05 & 0.00 & 100.0 \\
\hline PCTCONDO & Percentage condominium housing units in 2009 (\%) & 2.84 & 10.80 & 0.00 & 100.0 \\
\hline CHGVAL & Percentage change in as sessed housing value $(2004-2008)(\%)$ & 170.28 & $1,677.57$ & -100.00 & $44,108.4$ \\
\hline NEWHS & Percentage housing units buit between $1999-2008(\%)$ & 8.35 & 12.69 & 0.00 & 85.9 \\
\hline YEAR & Average year of housing units built & $1,971.00$ & 76.12 & 0.00 & $2,003.0$ \\
\hline CGTENURE & Change in homeowners hip rate $(2000-2008)$ & 0.00 & 3.99 & -17.15 & 42.8 \\
\hline CGVANC & Change in hous ing vacancy rate $(2000-2008)$ & 0.77 & 6.65 & -4.57 & 100.0 \\
\hline HHCOST & Hous ing cost burden $(\%, 2000)$ & 31.84 & 13.39 & 0.00 & 100.0 \\
\hline \multicolumn{6}{|c|}{ Land Use Characteristics (Independent Variables) } \\
\hline INDUSTRIAL & Number of industrial parcels in 2009 & 13 & 40 & 0 & \\
\hline MIDDLE & Located between US 1 and Florida's Turnoike (Yes, No) & & & & \\
\hline
\end{tabular}

Note: 1.326 block groups are located between U.S. 1 and Florida's Turnpike. (Variable Name: MIDDLE) 2. Residential foreclosure is measured by proportion of Certificates of Title transaction among all the residential parcels in each census block group. Thus this value is somewhat conservative. 
In this research foreclosure rates are defined as the percentage CET (Certificate of Title) parcels among all residential parcels for each block group. In Florida mortgage foreclosure follows the judicial procedure as defined under Chapter 45 of the Florida Statutes Title VI. In the order or the final judgment of the property filing for foreclosure, the civic court will direct the county clerk to sell the property at public sale on a specific date. Certificate of Title (CET) will be issued by the clerk if there is no objection to the sale of the property after 10 days of the filing of the Certificate of Sale. This research focuses on residential CET deeds during 2007 to February 2009 from Broward County Property Appraisers (BCPA). Therefore in this paper we focus on foreclosed properties because these properties might have the most significant impact on neighborhood change and the provision of opportunities. The CET deed transfer data are then merged with the Nielsen Claritas Census demographic estimate data in 2008 at the block group level. There are 690 block groups in Broward County and the total number of residential CET between 2007 and 2009 was 11,416. Frequencies of CET deeds are calculated for each block group and the foreclosure rate is derived from the ratio between the number of CET deeds and the number of total residential housing units. I use the number of total residential housing units instead of the number of housing units with a mortgage as the denominator of foreclosure rates. This is mostly out of the consideration that the spillover impact of foreclosed properties is not only limited to housing units with a mortgage.

Subprime rates are the percentage of high-cost subprime mortgages for 1-4 residential units among all outstanding residential mortgages. The shares of high-cost subprime mortgage (2004 - 2006) among all residential mortgages are derived from the HMDA (Home Mortgage Disclosure Act) data from Foreclosure Response, a non-profit organization with foreclosure resources to be used by local communities in foreclosure prevention and mitigation $^{6}$. This research uses the 2004-2006 subprime data because this is the time period which significantly contributes to the skyrocketing foreclosure issues which occurred during 2007 and 2010. This data also corresponds to the peak time of the housing bubble. High-cost subprime loans in this study are those with annual percentage rates (APR) about $3 \%$ higher than the rate on Treasury securities with comparable maturity for the first-lien mortgages, and about 5\% above the Treasury rate for the second-lien mortgages. In this study high-cost first-lien mortgages are used to identify subprime mortgages. All of the different types of subprime mortgages are based on mortgages outstanding for 1-4 family units. Both of the foreclosure and subprime lending rates are dependent variables in the OLS (Ordinary Least Square) regression models. The percentage subprime mortgage is also used as an independent variable to explain determinants of foreclosures.

Demographic characteristics take into account the number of total population, number of households, and household characteristics such as median income. Other population characteristics, for example average age, educational attainment (measured by the percentage population ( $\geq 25$ years age) with a college degree), racial composition, ethnicity composition (percentage Hispanic population), and percentage foreign-born population are also selected. Changes in these demographic characteristics from 2000 to 2008 are calculated to take into account the effect of "trigger events" on mortgage foreclosure.

Types of housing units, year housing being built, median housing value, housing occupancy and tenure status, and change in assessed housing value from 2004-2008 are used to measure housing attributes variables. The proportion of various types of housing, such as

6) The HMDA high cost loan data was retrieved from http://foreclosure-response.org/. More HMDA data can be found from FFIEC (Federal Financial Institutions Examination Council). 
single-family, multiple-family, condominiums, and mobile homes, among the total number of residential units is calculated in each block group. The change in homeownership rates and vacancy rates from 2000 to 2008 are used as control variables.

The foreclosure, demographic and subprime data are then merged with land use data. The percentage of industrial parcels among all property parcels in the block group is then calculated. Whether the block group is located within U.S.1 and Florida's Turnpike is treated as a dummy variable. Among the 690 block groups in Broward County, about 326 $(47.2 \%)$ are located between U.S. Highway 1 and Florida's Turnpike.

Analysis and Models. The first step of the analysis is to conduct basic descriptive statistic and spatial analysis. Various thematic maps are created to help explain the spatial patterns of foreclosure, subprime loans, demographic characteristics and land use patterns. There are three sets of regression models. The first one (Model 1) is to use land use characteristics to explain wealth and racial composition. The second model (Model 2) measures factors (land use, demographic characteristics, and housing attributes) contributing to percentage subprime mortgages. The third model (Model 3) measures the determinants (subprime lending, land use characteristics, and demographic and housing attributes) of foreclosure rates. Initially most of the selected variables listed in Table 1 are used in stepwise regression models 2 and 3 . The stepwise regression models helped reduce some multicollinearity among independent variables. Then variables that are selected by stepwise regression models with a significance level of less than 0.05 are included in the OLS (Ordinary Least Square) models to further measure determinants of subprime and foreclosures. Rerunning models 2 and 3 with a reduced number of variables yields results as indicated in Table 2 and Table 3. Since Model 1 is a simple linear regression model the results will not be specifically reported as a table; however, it will be explained briefly in the results section.

In addition to the series of regression models, maximum R-square improvement technique is used to explore the proportion of variance of foreclosure and subprime rates explained by different independent variables.

\section{Results and Discussion}

Descriptive Statistics. In Broward County subprime loans accounted for $30.06 \%$ of all residential mortgages between 2004 and 2006. Average non-working population in 2008 in each census block group was about $19.81 \%$ and the housing vacancy rate was about $11.03 \%$. Estimated median housing value was $\$ 307,244$ and the median household income was $\$ 54,122$. Among the total population, $20.87 \%$ were Hispanic, $62.88 \%$ were whites, and $26.07 \%$ were blacks. Averagely $79.46 \%$ of the housing stock was single-family housing units. The percentage change in assessed housing value was $170.28 \%$ from 2004 to $2008^{7}$ ). About $34.33 \%$ of the total population was foreign-born population in 2008 (see Table 1).

From Figure 1, we notice that black population is highly concentrated in three sections of the county. Most of the three sections are located between U.S. Highway 1 and University Dr., particularly between I-95 and Florida's Turnpike. In central Broward, the percentage black

7) The American Community Survey (ACS) 2005-2009 demographic estimates indicate some discrepancies with the Nielsen Claritas 2008 estimates. ACS implies that in Broward County there were about $29.6 \%$ foreign-born population and $35.2 \%$ spoke a language other than English at home. $66.8 \%$ (population 16 years and over) were in labor force and the median household income (in 2009 inflationadjusted dollars) was $\$ 51,731$. About $16.3 \%$ housing units were vacant and the median value was $\$ 260,500$. $65.7 \%$ population was white, $24.4 \%$ was black, and $23.1 \%$ was Hispanic. 
population is oftentimes over $70 \%$ in many block groups. The distribution of Hispanic population in the county slightly overlaps with the distribution of black population.

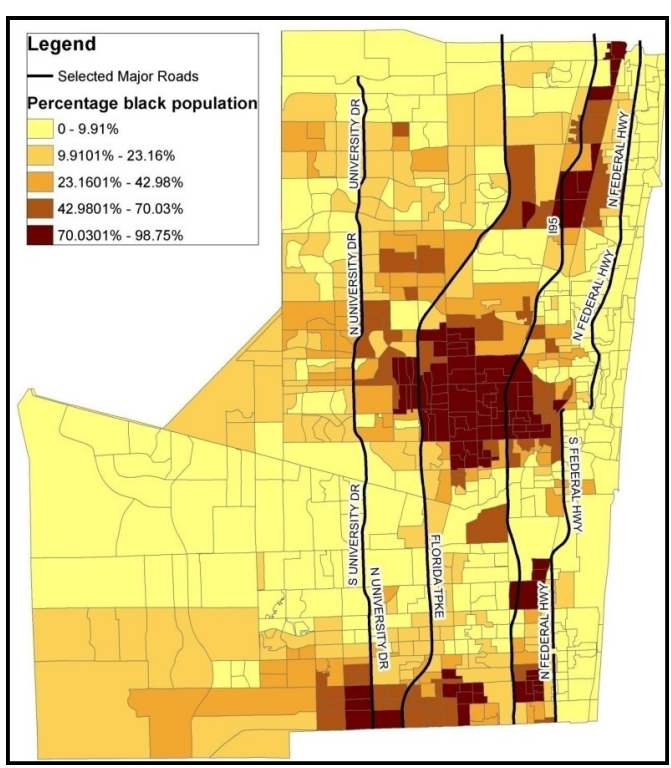

Fig. 2 - Percentage black population in Broward County (2008)

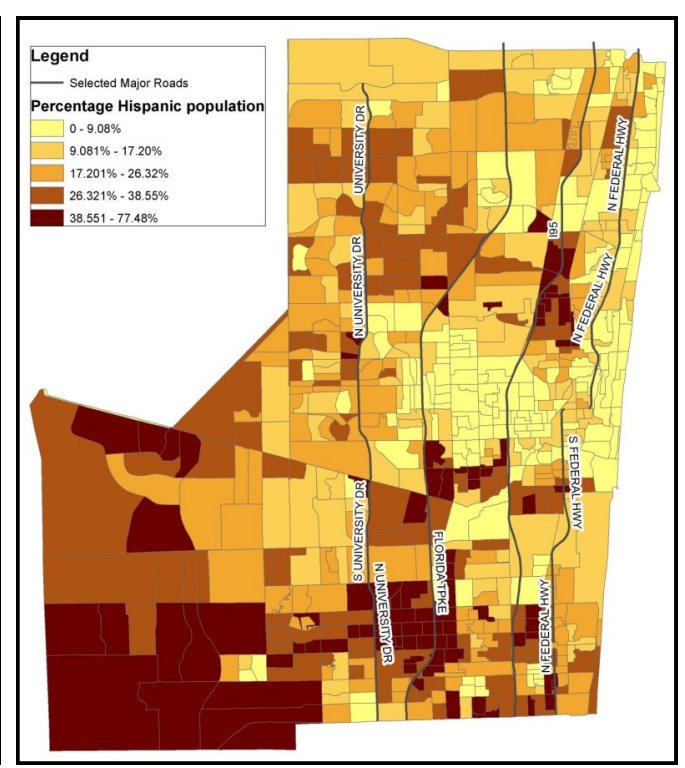

Fig. 3 - Percentage Hispanic population in Broward County (2008)

The distribution of high-cost subprime loans in Broward is shown in Figure 3. Most block groups with more than $40 \%$ of subprime loans among all mortgage outstanding are located between University Dr. (on the west) and U.S. Highway 1 (on the east) (see Fig. 3). The spatial pattern of subprime lending is consistent with the spatial pattern of the concentration of black population. This further raises the question of whether land use planning, particularly the construction of highways, would contribute to racial segregation and stratify the geography of opportunities in a metropolitan area. The multivariate analysis in the following sections will help test whether we should reject the hypothesis that land use planning acerbated racial and housing market segregation, thus contributing to the concentration of high-cost subprime loans and mortgage foreclosures.

As mentioned in previous sections the foreclosure rate was calculated as the percentage CET (Certificate of Title) over all residential housing units in a census block group. Therefore the foreclosure data does not include other foreclosure properties which were not sold by the court. This construes the data limitation in this research. Although the spatial distribution of mortgage foreclosures (as illustrated in Fig. 4) represented by CET does not cover all the foreclosures, it might show the most challenging properties which are located in severely distressed neighborhoods. Although the spatial distribution of foreclosed properties does not noticeably resemble the distribution of high-cost subprime and the percentage black population, from Figure 4 we notice that a higher percentage of foreclosed homes is between University Dr. and U.S. Highway 1.

Exploring Figure 2 through Figure 5, we find that land use patterns might matter in helping 
shape the segregation of wealth and the housing market in the study area. Results from Model 1 indicate that whether block groups are located between U.S. 1 and Florida's Turnpike explains about $18.08 \%$ of the variance in median household income. Being in this area can reduce median household income by $\$ 20,766$.

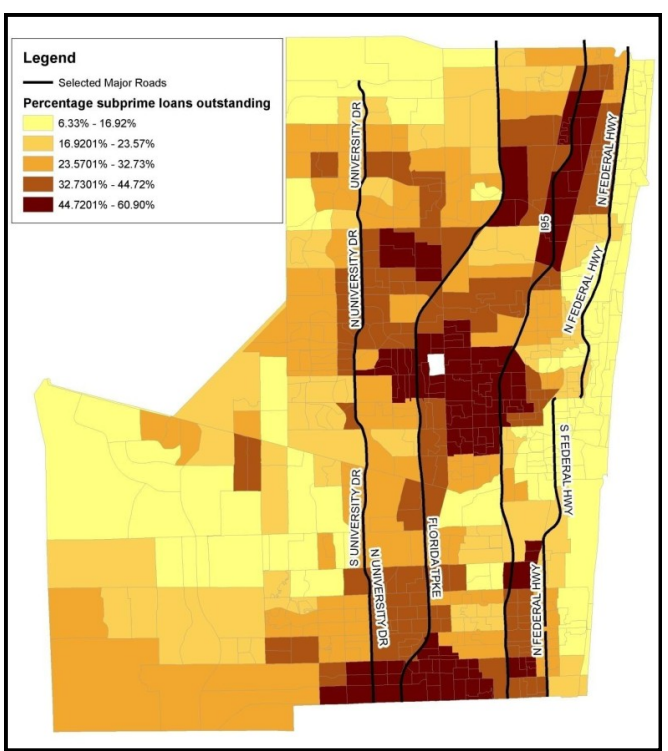

Fig. 4 - Percentage subprime loans outstanding in Broward County (2004-2006)

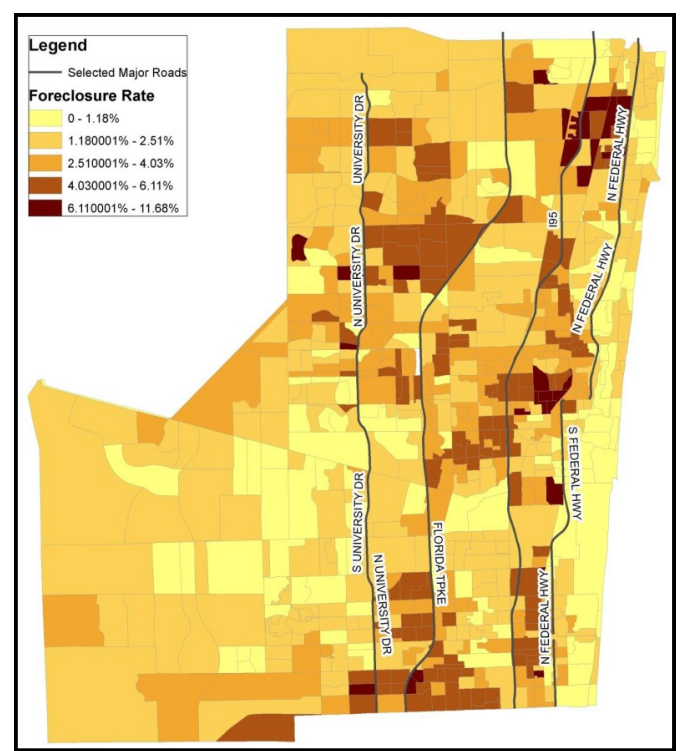

Fig. 5 - Foreclosure rates in Broward County (2007 - early 2009)

Moreover, being in this area also explains about $14.03 \%$ of the percentage black population in the county. Being in this area can potentially increase the percentage of black population by $21.50 \%$. When only considering the effect of land use on subprime and foreclosure locational variables are significant; however, when adding the demographic variables land use characteristics become insignificant.

Neighborhood Characteristics and the Subprime Lending. As discussed in the literature review section, certain neighborhood characteristics, such as race, education and income, significantly contribute to the spatial distribution of subprime mortgages (Bocian et al. 2008, Nichols et al. 2005, Courchane et al. 2004, Goldstein 2004, The U.S. Department of Housing and Urban Development and the U.S. Department of Treasury 2000, Belsky and Drew 2005). Controlling for all other variables, such as demographic characteristics, housing structural attributes, and land use and transportation patterns, we found that only certain demographic and housing attributes variables are significant. Somewhat deviated from our original hypotheses, the percentage white population negatively contributes to the percentage subprime lending (see Table 2). This implies subprime lending most likely relates to minority population, not necessarily just black population. The percentage Hispanic population is positively associated with subprime lending rates; however, its R-square contribution is very small. The percentage foreign-born population is not significant in the model. Instead the percentage new immigrants is negatively related to the percentage subprime loans. This indicates that foreign-born population who entered before 1990 are 
most likely to be homeowners and thus more relate to subprime lending. Demographically speaking, subprime loans are concentrated in neighborhoods with more minority population, a higher percentage of Hispanic population, a higher percentage of foreign-born population coming to the U.S. before 1990, less educated, and / or low- income population.

Table 2

OLS results: Variables related to percentage subprime lending

\begin{tabular}{|c|c|c|c|c|}
\hline Variable & $\begin{array}{c}\text { Parameter } \\
\text { Estimate }\end{array}$ & $\begin{array}{c}\text { Standard } \\
\text { Error }\end{array}$ & t Value & $\operatorname{Pr}>|t|$ \\
\hline Intercept & 50.2657 & 5.8157 & 8.64 & $<.0001$ \\
\hline \multicolumn{5}{|l|}{ Demographic Characteristics } \\
\hline Percentage White population & -0.3201 & 0.0139 & -23.04 & $<.0001$ \\
\hline Percentage Hispanic population & 0.1265 & 0.0205 & 6.16 & $<.0001$ \\
\hline Percentage new immigrants & -0.0756 & 0.0348 & -2.17 & 0.0303 \\
\hline Percentage population with college education & -0.1077 & 0.0304 & -3.54 & 0.0004 \\
\hline Median household income (log) & -2.5814 & 1.0536 & -2.45 & 0.0145 \\
\hline \multicolumn{5}{|l|}{ Housing Attributes } \\
\hline Homeownership rate & 0.0746 & 0.0152 & 4.91 & $<.0001$ \\
\hline Median housing value (log) & -4.6725 & 0.6616 & -7.06 & $<.0001$ \\
\hline Percentage single-family housing units & 0.0716 & 0.0198 & 3.62 & 0.0003 \\
\hline Percentage multiple-family housing units & 0.0045 & 0.0266 & 0.17 & 0.8651 \\
\hline Percentage condominium housing units & 0.0899 & 0.0284 & 3.17 & 0.0016 \\
\hline Percentage housing units built between 1999-2008 & -0.1166 & 0.0185 & -6.29 & $<.0001$ \\
\hline Average year of housing units built & 0.0396 & 0.0053 & 7.47 & $<.0001$ \\
\hline
\end{tabular}

Observing the effect of housing characteristics we notice that subprime loans tend to be in neighborhoods with lower housing values and older housing stock. Higher homeownership rates, and being single-family and condominiums all increase the likelihood of subprime loan concentrations. These housing characteristics correspond with the demographic characteristics in neighborhoods with concentrated subprime loans.

Maximum R-square improvement analysis indicates that the percentage white population accounts for about $66.86 \%$ of the variance in the percentage subprime lending, followed by the percentage population with a college degree (5.23\%) (see Table 4). This is consistent with some of the previous results that race, ethnicity and educational attainment all contribute to the spatial patterns of subprime lending. However, in Broward County, race alone, particularly the percentage minority population, is the largest factor to indicate the concentration of subprime lending.

Determinants of Mortgage Foreclosure. To further investigate factors contributing to foreclosure patterns in Broward the percentage subprime loans, demographic characteristics, housing structural attributes, and land use variables are incorporated into Model 3 (see Table 3 ). The percentage of subprime loans is found to be significantly positively related to foreclosures, so are selected demographic and housing variables. 
Table 3

OLS results: Variables related to percentage foreclosure rates

\begin{tabular}{|c|c|c|c|c|}
\hline Variable & $\begin{array}{c}\text { Parameter } \\
\text { Estimate }\end{array}$ & $\begin{array}{c}\text { Standard } \\
\text { Error }\end{array}$ & $\mathrm{t}$ Value & $\operatorname{Pr}>|t|$ \\
\hline Intercept & -1.0413 & 0.7924 & -1.31 & 0.1893 \\
\hline \multicolumn{5}{|l|}{ Subprime Characteristics } \\
\hline Percentage subprime loans & 0.0416 & 0.0063 & 6.64 & $<.0001$ \\
\hline \multicolumn{5}{|l|}{ Demographic Characteristics } \\
\hline Change in percentage black population & 0.0182 & 0.0092 & 1.98 & 0.0485 \\
\hline Average population age & -0.0369 & 0.0083 & -4.43 & $<.0001$ \\
\hline Percentage population with college education & -0.0344 & 0.0061 & -5.62 & $<.0001$ \\
\hline Change in percentage population with college education & 0.0461 & 0.0092 & 4.99 & $<.0001$ \\
\hline Percentage foreign-born population & 0.0089 & 0.0026 & 3.51 & 0.0005 \\
\hline \multicolumn{5}{|l|}{ Housing Attributes } \\
\hline Change in homeownership rate & -0.0280 & 0.0130 & -2.15 & 0.0318 \\
\hline Median housing value (log) & 0.2898 & 0.0660 & 4.39 & $<.0001$ \\
\hline Percentage single-family housing units & 0.0105 & 0.0033 & 3.18 & 0.0015 \\
\hline Percentage multi-family housing units & 0.0053 & 0.0049 & 1.08 & 0.2819 \\
\hline
\end{tabular}

Maximum R-Square Improvement

Table 4

\begin{tabular}{|l|c|}
\hline \multicolumn{1}{|c|}{ Variables } & Partial \\
\hline Model 1: Subprime Determ inants & \\
\hline Percentage White population & 0.6686 \\
\hline Percentage population with college education & 0.0523 \\
\hline Homeownership rate & 0.0220 \\
\hline Percentage housing units built between 1999-2008 & 0.0157 \\
\hline Other variables & 0.0500 \\
\hline Model R2 & 0.8086 \\
\hline & \\
\hline Model 2: Foreclosure Determinants & 0.3303 \\
\hline Percentage subprime loans & 0.0216 \\
\hline Percentage foreign-born population & 0.0146 \\
\hline Average population age & 0.0149 \\
\hline Change in percentage population with colledge educatio & 0.0547 \\
\hline Other variables & 0.4361 \\
\hline Model R2 & \\
\hline
\end{tabular}

Slightly different from the subprime determinants, changes in certain demographic characteristics, such as change in percentage black population, and change in percentage population with college education, contribute to foreclosures. Changes in percentage black population is positively related to foreclosure rates. This indicates when the percentage black population decreases foreclosure rates decrease; vice versa when the percentage increases foreclosure rates increase. On the other hand changes in the percentage population with college education negatively relate to foreclosures. This implies when the percentage population with college education decreases foreclosure rates increase; when the percentage population with college education increases foreclosure rates decrease. This is not surprising since education is often associated with disparities in credit scores and wealth. 
However, these two change variables cannot capture the assumed "trigger events" of foreclosures. This might indicate that foreclosures between 2007 and 2009 most likely is due to subprime and other omitted factors, not likely by "trigger events" such as loss of jobs.

Among the housing variables decreases in homeownership rate contribute to increases in foreclosures. This implies that it is likely that foreclosures concentrate in neighborhoods with more renters. Also no matter the housing unit is single-family or multiple-family it is not immune to foreclosures. This is different from the effect of housing attributes on subprime loans. Subprime loans mostly tend to concentrate in neighborhoods with more homeowners.

Limited research on nativity status and foreclosures implies that Hispanic households more or less likely relate to a higher chance of foreclosures than comparable white households, depending on whether they had a home purchase mortgage (more likely) or a refinance mortgage (less likely) (Allen 2001). This research indicates the percentage foreign-born population positively contributes to foreclosure rates in neighborhoods, no matter when they come to the U.S. This holds true regardless ethnicity status.

Average household age is negatively related to foreclosures. Florida has been one of a few states with a high percentage older population ( 65 or older) and the average is more than $17 \%$ (The Federal Interagency Forum on Aging-Related Statistics 2010). Research finds that predatory lending and subprime lending tend to target racial minorities and the senior population (Consumers Union 2002), which increased their vulnerability of potential foreclosures. This does not hold true in South Florida, when controlling for other socioeconomic factors. The results indicate neighborhoods with younger population witness more foreclosures. This further indicates that most likely foreclosures are concentrated in neighborhoods with a higher percentage subprime loans, a higher percentage foreign-born population, and predominantly renter neighborhoods.

Counter-intuitively median housing values are positively related to the concentration of foreclosures. This could result from the potential multicollinearity not being fully controlled through the stepwise regression process. This can also be attributed to data limitations where the median housing value in 2008 was estimated based on the 2008 American Community Survey data. In 2008 housing values have not decreased dramatically compared to the boom years of 2005-2007. This could also indicate the effect of negative equity on foreclosures when property values started to drop significantly in 2009 and 2010 . The effect of housing values on foreclosures is further tested by incorporating the percentage change in assessed housing values from 2004 to 2008. Controlling for all other factors, the percentage change in assessed housing values from 2004 to 2008 does not significantly contribute to the differences in foreclosure rates. The effect of housing values on foreclosures needs further investigation since the assessed housing value by the County might not be the best representation of the market value.

The maximum R-square analysis indicates that among all select variables the percentage subprime lending contributes about $33.03 \%$ of the variance of foreclosures. Thus without considering omitted variables subprime loans is the largest contributor to foreclosures. However, the R-Square of the model is only about 0.42 , which indicates that other omitted variables account for more than $50 \%$ of the variance of foreclosures. It is not clear what other factors might be among the omitted variables. Since we use foreclosed properties (CET) to measure foreclosures the omitted variables might relate to factors such as individual housing attributes, investor behavior, foreclosure behavior of financial institutions, or the status of pre-foreclosure sales. 


\section{Conclusions}

All the analysis presented in previous sections help us better understand the geography of subprime and foreclosures in South Florida. As in other metropolitan areas, the distribution of wealth and socioeconomic characteristics in this region is segmented. However, the segmentation no longer follows a dichotomous division of central city and suburbs, because of the unique geography of the region. Lower income neighborhoods are linearly bounded and located between the coast and suburbs. The areas with concentrated low-income neighborhoods also have the largest portion of industrial land uses, responding to convenient logistics adjacent to interstate highways (e.g. 1-95), railways (e.g. CSX and commuter Tri-rail), and toll freeways (e.g. Florida's Turnpike). Although the focus of this research is not to make a clear argument that transportation promotes housing market segmentation in this region, it is intriguing to see the linkage between land uses, transportation planning, and the distribution of wealth. Later, this evidently links to the spatial distribution of subprime lending in this region. The analysis indicates that the original hypotheses hold true. However, among determinants of subprime loans, the percentage minority population, not just black population, mostly links to the distribution of subprime loans. Hispanic population and foreign-born population who entered the U.S. before 1990 are also significantly related to subprime loans. The dynamics of foreclosures are slightly different from those of subprime loans. Change in black population and foreign-born population in general also contribute to foreclosures. Compared to subprime loans which target owner neighborhoods, foreclosures tend to concentrate in neighborhoods with a higher percentage of renters. Ethnic status is not a significant predictor of foreclosures. Among selected variables, the percentage foreign-born population follows the percentage subprime loans in contributing to the variance of foreclosures.

The descriptive and regression analysis all indicate a clear picture that subprime lending is concentrated in areas with a higher percentage minority population, lower income, lower educational attainment, older housing stock, a higher percentage of foreign-born population, and a higher percentage Hispanic population. Further analysis of incorporating subprime loans and other variables indicates that the spatial distribution of foreclosures does not follow a clear pattern. The effect of different variables on foreclosures is rather vague and the issue of omitted variables is more prominent, compared to factors explaining subprime lending. The residual analysis of the foreclosure regression (Model 3) does not show a clear pattern as well. Data limitation of using CET properties, instead of foreclosure filings, might impose precision problems in the analysis.

The concentration of poverty, subprime loans, and mortgage foreclosures in minority neighborhoods imposes significant challenges in urban planning and redevelopment. Preventing continued decay in these neighborhoods is a daunting, or less prioritized, task facing local governments. Neighborhoods with high foreclosure rates and the concentration of poverty are less likely to attract investment, which will further deteriorate the conditions in these neighborhoods. Much of the redevelopment efforts have focused on attracting wealthier residents to these areas. These tactics tend to displace original low-income residents and shifts poverty from one area to another.

Due to natural constraints of geological morphology in Florida, linear highway and rail patterns are unavoidable; however, future planning should consider the socioeconomic impact of these major projects on the concentration of poverty and how they helped shift geography of opportunities. Despite of their significant benefits in shortening travel time, alleviating urban traffic, stimulating economic goods distributing, and nurturing the emerge 
of new centers, surface freeways have been criticized for its negative impact on property values and the living environment, particularly in an urban environment. They might contribute to urban decay and housing market segregation. Surface freeways divide neighborhoods, especially those impoverished ones or ones lacking political or constituent support, and force affected neighborhoods further losing their vibrancy and connectivity. Technical improvement (such as elevated or underground highways ${ }^{8}$ ) might help reduce the negative impact of freeways on neighborhoods and households. Urban green space and multipurpose pedestrian and biker trails can be developed underneath the elevated overpass highway system. Promoting public transit ridership will help promote mobility, particularly in distressed neighborhoods. Increased mobility will help mobilize jobs, thus helping economically stabilize these neighborhoods.

Redevelopment efforts need to divert to areas severely affected by subprime lending and foreclosures. The definition of Florida Statutes on "blight" and "slum" is vague $^{9)}$, which vetoes local municipalities more flexibility in choosing areas to redevelop. Oftentimes the areas that mostly need redevelopment might not be in the agenda. The scope of the Neighborhood Stabilization Program is usually limited and unlikely to address the concentration of foreclosures in a large scale (Woodstock Institute 2011).

Up to December 2011, Broward County has only acquired 57 single-family homes, completing 21 rehabilitation and resell properties to eligible households (three to low income households). The county has acquired 11 multifamily properties (79 units) and has completed rehabilitation of 20 properties and renting of 13 units. Additionally, the county has given downpayment assistance to 10 households, among which 5 were low income households (Broward County Housing Finance and Community Development Division 2011). All these might not be sufficient to provide affordable housing for low-income households and households who lost their homes to foreclosure.

Future research should focus on how the construction of these linear highway and rail systems have contributed or linked to neighborhood change. The comparison between foreclosure new filings and foreclosed properties can tell which properties are easier to avoid foreclosures. Careful analysis of affordable housing needs and spatial mismatch should be conducted to choose proper redevelopment strategies. This will also help policy makers and urban planners use land use and transportation planning tools to create more opportunities for disadvantaged communities.

\section{References}

ALLEN, R. (2011), The relationship between residential foreclosures, race, ethnicity,

8) Future research needs to be done to examine whether these elevated or underground highways reduces social separation.

9) Florida Statutes Chapter 163 indicates that finding "blight" or "slum" must satisfy two or more of the following standards: real estate values showing no appreciable increase; faulty lot layout in relation to accessibility, adequacy, usefulness; unsafe or unsanitary conditions; deterioration of site or other improvements; inadequate or outdated building density patterns; falling commercial lease rates compared to the rest of the City/County; tax or special assessment delinquency exceeding the value of the land; residential and commercial vacancy rate higher than the City/County; incidence of crime higher than the remainder of the City or County; higher rate of calls for Fire/EMS than the remainder of the City or County; more violations of the Building Code than in the reminder of the City/County; diversity of ownership affecting the free alienability of land; governmentally owned property with adverse environmental conditions. This type of standards of finding "blight" or "slum" leaves controversial and vague delineation of areas to establish Community Redevelopment Agencies (CRAs). 
and nativity status, Journal of Planning Education and Research, 31 (2), pp. 125-142.

APGAR, W., and DUDA, M. (2004), Mortgage foreclosure trends in Los Angeles: Patterns and policy issues, Research prepared for Los Angeles Neighborhood Housing Services.

BEEN, V. (1994), Locally undesirable land uses in minority neighborhoods: Disproportionate siting or market dynamics, The Yale Law Journal, 103 (6), pp. 1383-1422.

BELSKY, E. S., and DREW, R. B. (2007), Taking stock of the nation's rental housing challenges and a half century of public policy responses [Prepared for Revisiting rental housing: A policy summit],, The Joint Center for Housing Studies of Harvard University.

BIRCH, D. L. (1971), Towards a stage theory of growth, Journal of the American Institute of Planners, 37 (2), pp. 78-87.

BOCIAN, D. G., ERNST, K.S., and LI, W. (2008), Race, ethnicity and subprime home loan financing, Journal of Economics and Business, 60, pp. 110-124.

BOSTIC, R. W., and LEE, K. O. (2008), Homeownership: America's dream [National Poverty Center Policy Brief \#15, November 2008]. Ann Arbor, MI: National Poverty Center, University of Michigan.

BURGESS, E. (1925), The growth of the city, in The City, eds R. Park, E. Burgess, R. McKenzie. Chicago, Illinois, University of Chicago Press.

BROWARD COUNTY HOUSING FINANCE AND COMMUNITY DEVELOPMENT DIVISION. (2011), Neighborhood Stablization Program Quarterly Performance Report for October 1, 2010 - December, 2010. Retrieved from: http://wwww.broward.org/housing/Pages/ Default.aspx.

CALEM, P. S., HERSHAFF, J. E., and WACHTER, S. M. (2004), Neighborhood patterns of subprime lending: evidence from disparate cities, Housing Policy Debate, 15 (4), pp. 603-622.

CASKEY. J. (1994), Fringe banking: Check-cashing outlets, pawnshops, and the poor. New York, Russell Sage Foundation.

CASKEY. J. (2002), Bringing unbanked households into the banking system. Washington, DC., The Brookings Institution. Retrieved from: http://www.brookings.edu/es/ urban/capitalxchange/article10.htm.

CHAN, S., GEDAL, M., BEEN, V., and HAUGHWOUT, A. (2010), The role of neighborhood characteristics in mortgage default risk: Evidence from New York City, Working Paper, NYU Wagner School and Furman Center for Real Estate and Urban Policy.

COLEMAN, M. IV, LACOUR-LITTLE, M., and VANDELL, K. D. (2008), Subprime lending and the housing bubble: Tail wags dog?, Journal of Housing Economics, 17, pp. 272290.

CONSUMERS UNION (2010), Elderly in the subprime market, Retrieved from: http:/I www.

COURCHANE, M. J., SURETTE, B. J., and ZORN, P. M. (2004). Subprime borrowers: Mortgage transitions and outcomes, Journal of Real Estate Finance and Economics, 29 (4), pp. 365-92.

DING, L., RATCLIFFE, J., STEGMAN, M.A., and QUERCIA, R.G. (2008), Neighborhood patterns of high-cost lending: The case of Atlanta, Journal of Affordable Housing, 17 (3), pp. 193-217.

DUNN, M. (1997), Black Miami in the Twentieth Century, University Press of Florida.

DUNCAN, D. (2006), Fourth general session: Economic/Housing outlook, PowerPoint slides, Retrieved from http://www.mortgagebankers.org/files/ Conferences/2006/93rdAnnualConvention/MBA DougDuncan4thGeneralSession final.pdf.

FITZGERALD, J., and LEIGH, N. G. (2002), Economic Revitalization: Cases and Strategies for City and Suburb, Sage Publications.

GALSTER, G., and KILLEN, S. (1995), The geography of metropolitan opportunity: a 
reconnaissance and conceptual framework, Housing Policy Debate, 6 (1), pp. 73-102.

GOLDSTEIN, I. (2004), Bringing subprime mortgages to market and the effects on lower-income borrowers, Joint Center for Housing Studies, Harvard University.

GOLDSTEIN, I., MCCULLOUGH, M., PARKER, A., and UREVICK-ACKELSBERG, D. (2005), Mortgage foreclosure filings in Pennsylvania, Philadelphia: Reinvestment Fund. Retrieved from: http:///www.trfund.com/policy/PA_Foreclosures.htm.

GRAMLICH, E. M. (2007), Subprime mortgages: America's latest boom and bust, Washington DC, Urban Institute Press.

GROVER, M, SMITH, L., and TODD, R. M. (2008), Targeting foreclosure interventions: An analysis of neighborhood characteristics associated with high foreclosure rates in two Minnesota Counties, Journal of Economics and Business, 60, pp. 91-109.

HOYT, H. (1933), One hundred years of land values in Chicago, Chicago, IL, Illinois University of Chicago Press.

HUD (The U.S. Department of Housing and Urban Development) (1992), Report to Congress on the Home Loan Mortgage Corporation, pp. 120-176.

IMMERGLUCK, D. (2008), From the subprime to the exotic: Excessive mortgage market risk and implications for metropolitan communities and neighborhoods, Journal of the American Planning Association, 74 (1), pp. 59-76.

IMMERGLUCK, D., and SMITH, G. (2005), Measuring the effect of subprime lending on neighborhood foreclosures: Evidence from Chicago, Urban Affairs Review, 40 (3), pp. 362-389.

KINGSLEY, G. T., and PETTIT, K. L.S. (2009), High-cost and investor mortgages: Neighborhood patterns, Metropolitan Housing and Communities Center.

LI, Y., and MORROW-JONES, H. (2010), The impact of residential mortgage foreclosure on neighborhood change and succession, Journal of Planning Education and Research, 30 (1), pp. 1-22.

NATIONAL ASSOCIATION OF REALTORS, RESEARCH DIVISION (2004), Rising Foreclosure Rates in Indiana: An Explanatory Analysis of Contributing Factors, Retrieved from: http://www.mibor.com/ pdfs/ForeclosureStudy2004.pdf.

NPR (National Public Radio) (2010), 1-95: The road most traveled, Retrieved from:

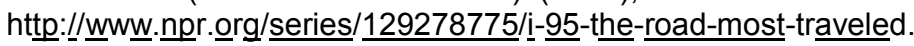

NEWMAN, K., and WYLY, E. K. (2004), Geographies of mortgage market segmentation: The case of Essex County, New Jersey, Housing Studies, 19 (1), pp. 53-83.

NICHOLS, J., PENNINGTON-CROSS, A., and YEZER, A. (2005), Borrower selfselection, underwriting costs, and subprime mortgage credit supply, Journal of Real Estate Finance and Economics, 30 (2), pp. 197-219.

NOONAN, D. S. (2006), Urban environments and neighborhood change: Exploring urban sorting beyond the featureless plain, Georgia Institute of Technology working paper.

QUERCIA, R. G., and STEGMAN, M. A. (1992), Residential mortgage default: a review of the literature, Journal of Housing Research, 3, pp. 341-379.

REALTYTRAC.COM. (2011), Broward County foreclosures, Retrieved from: http:// www.realtytrac.com/states/florida/broward-county.html.

RHEY R., and POSNER, A. (2004), The American Dream lost: Foreclosures in Pima County, Arizona, Prepared for Pima County Community Development and Neighborhood Conservation Department.

ROTHENBERG, J , GALSTER, G, BUTLER, R., and PITKIN, J. (1991), The maze of urban housing markets theory, practice and evidence, Chicago, Illinois, University of Chicago Press.

ROSENBAUM, J. REYNOLDS, L., and DELUCA, S. (2002), How do places matter? The geography of opportunity, self-efficacy and a look inside the black box of residential mobility, Housing Studies, 17 (1), pp. 71-82.

RUGH, J. S., and MASSEY, D.S. (2010), Racial segregation and the American 
foreclosure crisis, American Sociological Review, 75 (5), pp. 629-651.

SANDOR, R. L., and SOSIN, H. B. (1975), The determinants of mortgage risk premiums: a case study of the portfolio of a savings and loan association, The Journal of Business, 48 (1), pp. 27-38.

SCHIVELY, C. (2007), Understanding the NIMBY and LULU phenomena: Reassessing our knowledge base and informing future research, Journal of Planning Literature, 21 (3), pp. 255-266.

SEFTC (Southeast Florida Transportation Council) (2009), Southeast Florida 2035 regional transportation plan, Miami-Dade MPO, Broward MPO, Palm Beach MPO, Retrieved

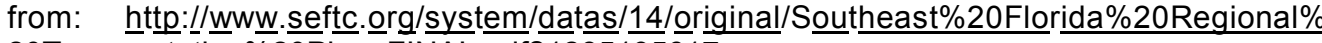
20Transportation\%20Plan_FINAL.pdf?1285195617.

SMITH, W. F. (1963), Forecasting neighborhood change, Land Economics, 39 (3), pp. 292-297.

SWEENEY, J. L. (1974), A commodity hierarchy model of the rental housing market, Journal of Urban Economics, 1 (3), pp. 288-323.

SUPREME COURT OF FLORIDA (2009), Final report and recommendations on residential mortgage foreclosure cases, No. AOSC09-54, Retrieved from: http:// www. floridasupremecourt.org/pub info/documents/AOSC09-54 Foreclosures.pdf

SQUIRES, G. D., and KUBRIN, C. E. (2005), Privileged places: Race, uneven development and the geography of opportunity in urban America, Urban Studies, 42 (1), pp. 47 -68 .

SAWYER, N. and TEMKIN, K. (2004), Analysis of alternative financial service providers, Washington D.C., Fannie Mae Foundation and the Urban Institute.

STOCK, R. D. (2001), Predation in the sub-prime lending market: Montgomery County, Prepared for Lutheran Social Services of the Miami Valley.

TEMKIN, K., and ROHE, W. (1996), Neighborhood Change and Urban Policy, Journal of Planning Education and Literature, 15 (3), pp. 159-179.

THE FEDERAL INTERAGENCY FORUM ON AGING-RELATED STATISTICS (2010), Older Americans 2010: Key Indicators of Well Being.

U.S. DEPARTMENT OF HOUSING AND URBAN DEVELOPMENT and THE U.S. DEPARTMENT OF THE TREASURY (2000), Curbing predatory home mortgage lending, Washington DC

VANDELL, K. D., and TRIBODEAU, T. (1985), Estimation of mortgage defaults using disaggregate loan history data, Real Estate Economics, 13 (3), pp. 292-316.

WOODSTOCK INSTITUTE (2011) (March), Troubled foreclosed properties, servicer accountability, and the Chicago region: Findings and proposals from a February 2011 briefing.

WYLY, E. K. (2002), Mortgaged metropolis: Evolving urban geographies of residential lending, Urban Geography, 23 (1), pp. 3-30.

Initial submission, July 26, 2011

Revised submission, November 23, 2011

Final acceptance, November 30, 2011

Correspondence: Florida Atlantic University, 111 E. Las Olas Blvd. Ft. Lauderdale, FL 33301, U.S.A.

E-mail: yli22@fau.edu 
